\title{
LIFE CYCLE OF TRYPANOSOMA CRUZI (Y STRAIN) IN MICE
}

Pedro Luiz Silva Pinto, Roberto Takami, Elizabeth V. Nunes, Carmem S. Guilherme, Oswaldo Cruz Oliveira Jr., Joaquim Gama-Rodrigues and Masayuki Okumura

PINTO, P.L.S. et al. - Life cycle of Trypanosoma cruzi (Y strain) in mice. Rev. Hosp. Clin. Fac. Med. S.Paulo 54, (5):141-146, 1999.

SUMMARY: Since 1958, we have studied experimental Chagas' disease (CD) by subcutaneous inoculation of 1,000 blood forms of Trypanosoma cruzi (Y strain) in Balb/C. mice. Evolution of parasitemia remained constant, beginning on the $5^{\text {th }}$ and $6^{\text {th }}$ day of the disease, increasing progressively, achieving a maximum on about the $30^{\text {th }}$ day. After another month, only a few forms were present, and they disappeared from the circulation after the third month, as determined from direct examination of slides and the use of a Neubauer Counting Chamber. These events coincided with the appearance of amastigote nests in the tissues (especially the cardiac ones), starting the first week, and following the Gauss parasitemia curve, but they were not in parallel until the chronic stage. In 1997, we began to note the following changes: Parasites appeared in the circulation during the first week and disappeared starting on the $7^{\text {th }}$ day, and there was a coincident absence of the amastigote nests in the tissues. A careful study verified that young forms in the evolutionary cycle of $T$. cruzi (epi + amastigotes) began to appear alongside the trypomastigotes in the circulation on the $5^{\text {th }}$ and $7^{\text {th }}$ post-inoculation day. At the same time, rounded, oval, and spindle shapes were seen circulating through the capillaries and sinusoids of the tissues, principally of the hematopoietic organs. Stasis occurs because the diameter of the circulating parasites is greater than the vessels, and this makes them more visible. Examination of the sternal bone marrow revealed young cells with elongated forms and others truncated in the shape of a "C" occupying the internal surface of the blood cells that had empty central portions (erythrocytes?). We hypothesize that there could be a loss of virulence or mutation of the $\mathrm{Y}$ strain of Trypanosoma cruzi.

DESCRIPTORS: Experimental Chagas' disease. American trypanosomosis. Amastigotes. Epimastigotes. Trypomastigotes.

The discovery of CHAGAS' DISEASE $(\mathrm{CD})^{1}$ is an outstanding event in the history of medicine. One scientist discovered the etiological agent, the entire biological cycle, and the course of the disease even before seeing an affected patient.

The isolation of $\mathrm{Y}$ strain of Trypanosoma cruzi by Nussenzweig $(1950)^{2}$ was an important step for investigators of $\mathrm{CD}$, because of the virulence of the parasite, which killed almost all the animals inoculated intraperitoneally with high amounts by around two to three weeks of infection.

These parasites had a stable and constant life cycle in the laboratory animals and produced standardized hematological and histopathological results, making them ideal for experimental studies.
In our experience at the University of S. Paulo Medical School (FMUSP) since $1958^{3,4}$, the T. cruzi (Y strain) behaved uniformly until the end of $1997^{5}$. At this time, the course of the disease in laboratory animals began to change similar to the description of Morais-Rego ${ }^{6}$ in 1956.

Parasitemia disappeared soon after the first outbreak, with mice no longer succumbing from the disease during the first month. The same behavior of the animals was detected by us at the

From the Departments of Pathology and Gastroenterology of the Adolfo Lutz Institute, University of São Paulo School of Medicine, São Paulo - Brazil and Institute of Tropical Medicine, São Paulo - Brazil.
Tropical Medicine Institute of S. Paulo (IMT.SP) and Adolfo Lutz Institute (IAL).

Because of these unexpected observations, we conducted a complete review of the protozoan's biology, starting from the initial stage of its reproductive cycle.

\section{MATERIALS AND METHODS}

Twenty young Balb/C male mice, ranging from $18-20$ grams, were inoculated peritoneally with 100,000 forms of Trypanosoma cruzi (Y strain), divided into 3 groups ( $\mathrm{A}, \mathrm{B}$, and $\mathrm{C}$ ), and inoculated weekly. On $2^{\text {nd }}-5^{\text {th }}$ - and $7^{\text {th }}$ day after inoculation, two mice from each group were sacrificed and submitted to parasitologic, histopathologic 
studies, and for imprint of liver, spleen and bone marrow.

Blood for parasitemia study was taken from the tail, orbital region, and heart by direct puncture.

The smear was stained with Giemsa solution and the parasites counted by scanning 100 microscopic fields of the slide.

The chest, abdomen, and skulls of the sacrificed animals were opened, imprints of the bone marrow, liver and spleen were done, fragments of tissue were fixed immersed in $10 \%$ buffered formalin solution for four days, and 5 micron sections were cut for histological section and stained with hematoxylin-eosin (HE).

\section{RESULTS}

Second post-inoculation day: Examination of the peripheral blood was negative for trypomastigotes. However, rounded, oval, and elongated figured cells were found in the cellular interstices (in the sinusoids and capillaries), principally in the brain, liver and kidneys (Fig. 1-5).

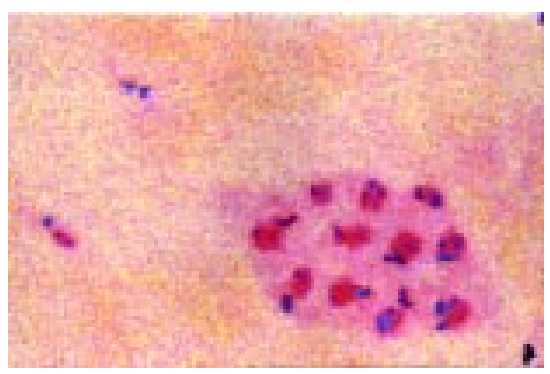

Figure 1 - Peripheric vessel: - A- epi and tripomastigotes forms in blood stream.

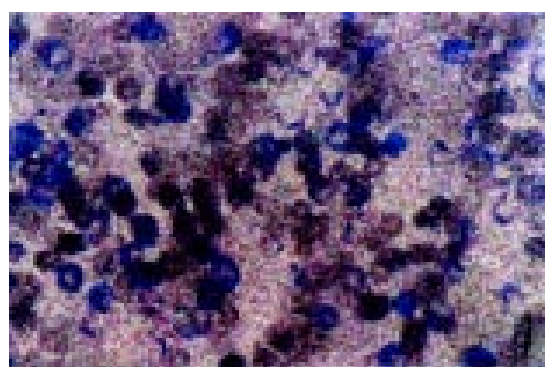

Figure 4 - Peripheric vessel: amastigotes and tripomastigotes in the circulation.

Table 1

\begin{tabular}{|c|c|c|c|c|c|c|c|c|c|c|c|c|}
\hline \multirow[b]{2}{*}{ MICE } & \multirow[b]{2}{*}{ DATE } & \multicolumn{3}{|c|}{ PARASITEMIA } & \multicolumn{3}{|c|}{ PARASITISM } & \multicolumn{3}{|c|}{ IMPRINT } & \multirow[b]{2}{*}{ GAN } & \multirow[b]{2}{*}{ TIMr } \\
\hline & & TRIPO & EPI & AMAS & NEST & LIVER & SPLEEN & LIVER & SPLEEN & BM & & \\
\hline A1 & 2 & 0 & 0 & 0 & 0 & $*$ & 0 & 0 & 0 & 0 & 0 & 0 \\
\hline A2 & 2 & - & - & - & - & $*$ & - & - & - & - & - & $*$ \\
\hline B1 & 2 & - & - & - & - & 0 & - & - & - & - & - & - \\
\hline B2 & 2 & - & - & - & - & $*$ & - & - & - & - & - & - \\
\hline $\mathrm{C} 1$ & 2 & - & - & - & - & 0 & - & - & - & - & - & - \\
\hline $\mathrm{C} 2$ & 2 & - & - & - & - & $*$ & - & - & - & - & - & - \\
\hline A1 & 5 & - & - & 68 & - & 0 & - & - & - & - & - & - \\
\hline A2 & 5 & 10 & 2 & 45 & - & 0 & 0 & 0 & 0 & 0 & 0 & 0 \\
\hline B1 & 5 & 23 & 18 & 0 & - & $* * *$ & - & - & - & - & - & - \\
\hline B2 & 5 & 13 & 16 & 0 & - & $*$ & - & - & - & - & - & - \\
\hline $\mathrm{C} 1$ & 5 & 14 & 0 & 0 & - & $* * *$ & - & - & - & - & - & - \\
\hline $\mathrm{C} 2$ & 5 & 8 & 0 & 0 & - & $* * *$ & - & - & - & - & - & - \\
\hline A1 & 7 & 130 & 144 & 23 & + & +++ & +++ & - & - & - & - & - \\
\hline A2 & 7 & 239 & 114 & 302 & + & +++ & ++ & - & - & - & - & - \\
\hline B1 & 7 & 210 & 470 & 37 & - & +++ & ++ & - & - & - & - & - \\
\hline B2 & 7 & 158 & 293 & 39 & - & +++ & +++ & - & - & - & - & - \\
\hline $\mathrm{C} 1$ & 7 & 939 & 47 & 39 & - & +++ & +++ & - & - & - & - & - \\
\hline $\mathrm{C} 2$ & 7 & 1131 & 37 & 67 & - & +++ & ++ & - & - & - & - & - \\
\hline D1 & - & - & - & - & - & - & - & +++ & +++ & ++++ & 0 & 0 \\
\hline D2 & - & - & - & $\mathrm{T}$ & - & - & - & ++ & +++ & +++ & 0 & 0 \\
\hline
\end{tabular}

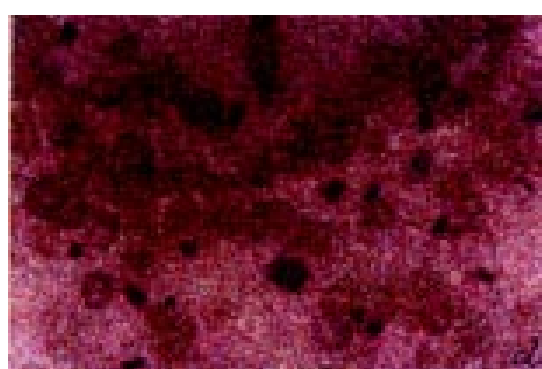

Figure 2 - Peripheric vessel : amastigotes and epimastigotes free in the circulation.

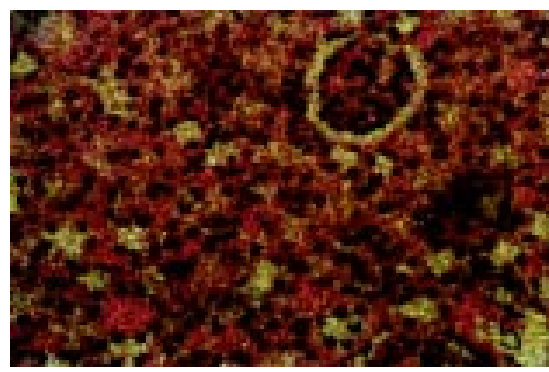

Figure 5 - Kidney: glomerular, parasites circulating in capillaries and sinusoids.

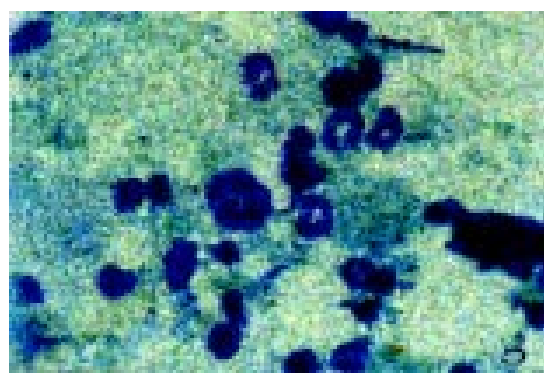

Figure 3 - Bone marrow (imprint) parasites frees and intraglobular.

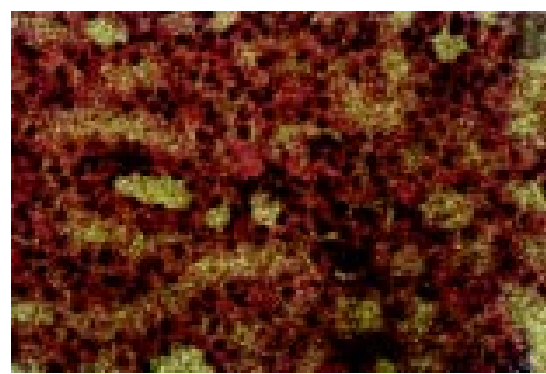

Figure 6 - Kidney: Tubular: parasite circulating in capillaries and sinusoids (imprint) globules with circular. 


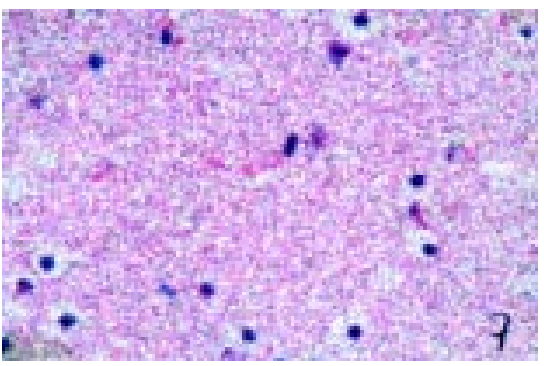

Figure 7 - Brain: microcirculation, parasites with stasis.

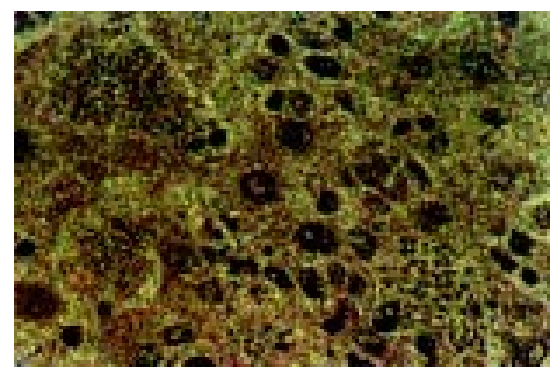

Figure 10 - Liver: high parasitism - amastigotes nests in the sinusoids.

Fifth post-inoculation day: There was the initiation of irregular distribution of parasites in the peripheral blood. Parasites were seen predominantly in the blood taken from the cardiac cavity; fewer were seen in the blood from the orbital region and the tail. Surprisingly, young developing elements (amastigotes and epimastigotes) were visible alongside the trypomastigotes (Fig. 6-8). Interstitial parasites increased in the liver, kidneys, and brain, and for the first time, amastigotes nests were observed in the spleen.

Seventh post-inoculation day: Circulating parasites increased, with irregular distribution of the amastigotes, epimastigotes, and trypomastigotes, with a maximum of 302,490 , and 1131 developing forms, respectively. (Table 1). Parasitism, characterized by the presence of parasites in the tissue interstices underwent changes, since amastigotes nests began to appear in the capillaries and sinusoids of the liver and spleen, predominating over the free forms (Fig. 10-12).

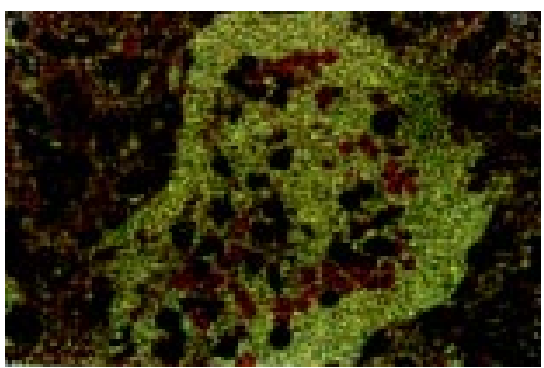

Figure 8 - Liver: centrolobular vein: parasite free.

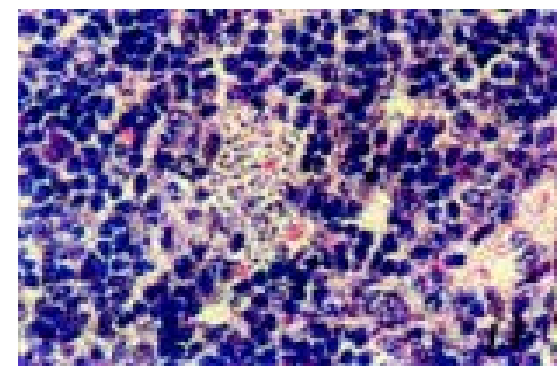

Figure 11 - Spleen: white pulp amastigote nest.

The imprints of the liver, spleen and bone marrow were positive. Our attention was called to the sternal bone marrow were addition to the young forms of the blood cells (WBC's and RBC's), rounded forms were found within the globules with chain links figures surrounding the empty center and bizarre figures such as fish, amphibians, reptiles, etc. (Fig. 9).

\section{DISCUSSION}

This study was designed to investigate the course of the $\mathrm{Y}$ strain of $T$. cruzi in mice inoculated peritoneally, especially during the first seven days of the disease, the initial reproductive stage before the appearance of the first parasitic outbreak.

Second day - Examination of the peripheral blood did not reveal any parasites.

The parasites were detected on the second day after inoculation, free forms of trypomastigotes were noted in the interstitium and capillaries, especially in

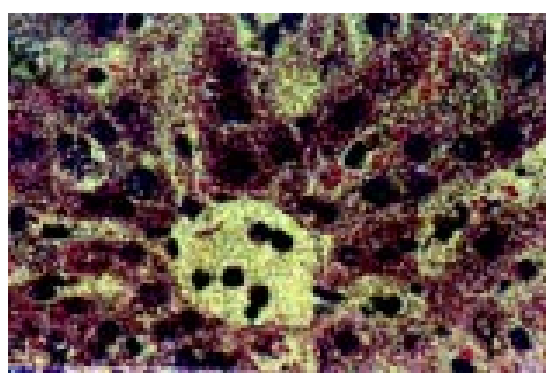

Figure 9 - Liver: centrolobular vein and sinusoids with parasite free.

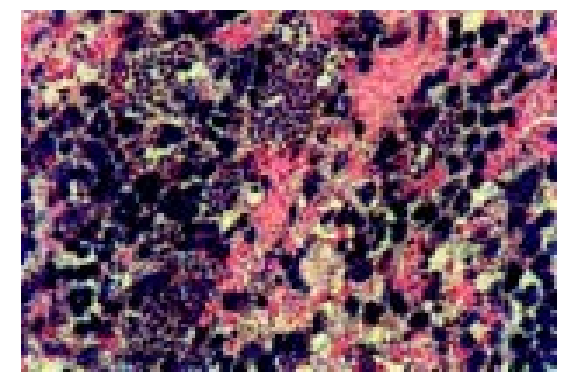

Figure 12 - Spleen: red pulp with amastigote nests.

liver and brain, showing circular, elliptical and spindle shapes (Fig. 1-2).

These figures were initially present in small number $(+)$ intensifying and attaining their maximum, two days later.

Fifth day - Parasitemia began from the $5^{\text {th }}$ day, when for the first time in these 40 years of manipulation, young forms (epi and amastigotes) appeared together with the classical trypomastigotes forms.

Parasitism reached the score of $(++++)$ in the liver, brain, heart, lung, thymus, kidneys and small bowel. They were linked to amastigotes nests starting from the $5^{\text {th }}$ day $(++$ or +++$)$. reaching the maximum $(++++)$ two days later, when the nests predominated.

Parasites were also discovered in the microcirculation of the organs, obstructing their lumen, raising a doubt as to whether the cells that harbored the protozoans were or were not those of the Mononuclear Phagocyte System $(\mathrm{SFM})^{7}$, contrasting with the endothelial layer with normal cells. 
The microcirculation of the organs became more visible because of the presence of various shapes of parasites: circular, elliptical, elongated, rod or spindle shaped, with the RBC's clearly visible inside, probably constituted of nuclei, kinetoplasts and other corpuscular elements that promote stasis.

They were histochemically confirmed as T. cruzi and not endothelial cells, Kuppfer liver cells or SFM of other organs (Fig. 1 - 5).

Amastigotes nests were encountered in the spleen of one the animals for the first time.

On the $7^{\text {th }}$ day the number of $T$. cruzi ranged from 197 to 1235 per cubic millimeter. Amastigotes nests were exceptionally found in the cardiac blood of two animals coinciding with the appearance in the hepatic and splenic capillaries + sinusoids despite not finding them in the sternal blood marrow. This leads to the hypothesis that they originated in hemangioblasts $^{8.9 .10}$.

Imprints of sternal bone marrow, showed blood cells of young elements of WBC's together with some RBC's whose interiors displayed spots with a clear central halo, and even figures similar to chain links occupying the cytoplasm next to the membrane. This brought to mind the parasitic WBC's reported by Carlos Chagas ${ }^{1}$ (1909) the presence of integral ring-shapes, truncated into a $\mathrm{C}$ - shape and other elongated figures. When free in the medulla they acquired figures similar to fish, amphibians (tadpoles) and reptiles with fairly long undulating membranes, attaining the parasite, about two or three times the diameter of the a RBC's (Fig. 9).

Amazingly, the account of numerous free forms of $T$. cruzi in the blood stream emerged only 40 years later (Chagas $^{1}$ - 1909; Morais-Rego ${ }^{6}$ - 1956 and Silva Pinto et al. ${ }^{5}$ - 1997).

Could there be a loss of virulence or mutation ${ }^{11}$ of the strain of Trypanosoma cruzi?

The objective of this study was to draw the attention of the research community to the importance of performing stained blood smears to detect the $T$. cruzi instead of the fresh blood smears. This is because the fresh blood smears test as reported by Carlos Chagas is unreliable and so is the Neubauer count of the parasite cells and motionless of amastigotes.
Scientists, and especially immunologists, should be reminded that distribution of amastigote nests in the liver and spleen is not uniform. They tend to concentrate at the level of the poles and glandular surface, with the least number of parasites in the central portion. This is also observed in the spleen confirmed by the contrast between the abundance nests in the red and their rarity in the white pulp (Fig. 11-12).

\section{CONCLUSION}

For the first time since 1958, we have confirmed the presence of evolutionary young forms (epi and amastigotes together with trypomastigotes) of the Y strain of Trypanosoma cruzi in the circulating blood in mice.

ACKNOWLEDGEMENTS: We acknowledge Teresa Curi for helpful support for translation and Lia Aparecida dos Santos Negrão for secretarial assistance.
PINTO, P.L.S. e col. - Ciclo evolutivo do Trypanosoma cruzi (cepa Y) no camundongo branco (mus musculus.

L). Rev. Hosp. Clin. Fac. Med. S.

Paulo, 54 (5):141-146, 1999.
Desde 1958, nós estudamos a doença de Chagas experimental, inoculando 1.000 formas sanguicolas de Trypanosoma cruzi, Chagas-1909, (cepa Y) por via sub-cutânea em camundongos Balb/C, que manteve uma constância na evolução da parasitemia, iniciando no quinto e sexto dia de moléstia, aumentando progressivamente, atingindo o máximo ao redor 
do vigésimo, diminuindo a seguir até atingir o mínimo no final do trigésimo dia e desaparecimento do sangue circulante (pelo exame direto a fresco entre lâmina e lamínula ou pela contagem na Câmara de Neubauer) depois do terceiro mês, coincidindo com o aparecimento de ninhos de amastigotas nos tecidos, principalmente do cardíaco a partir da primeira semana, acompanhando a curva parasitêmica, porém não evoluindo paralelamente até a fase crônica.

Em 1997, começamos a verificar alteração no seu comportamento, pois, os parasitos surgiram no sangue circulante na primeira semana e a partir do sétimo dia desapareceram, coincidindo com a ausência de ninhos de amastigotas nos tecidos.

Num estudo minucioso, verificamos que começaram a aparecer formas jovens do ciclo evolutivo do T.cruzi (epi + amastigotas) ao lado de tripomastigotas na corrente sanguínea no quinto e sétimo dia da inoculação, coincidindo com formas arredondadas, ovaladas e fusiformes circulando pelos capilares e sinusóides dos tecidos, principalmente dos órgãos hematopoiéticos. É interessante frisar, que os parasitos circulantes, devido ao seu diâmetro ser maior que o dos vasos sanguíneos, provocam estáse a montante, tornando-os mais visíveis.

Examinando a medula óssea ester- nal, encontramos as formas jovens alongadas, outras truncadas em forma de $\mathrm{C}$ ocupando a superfície interna dos glóbulos, com a parte central vazia, dando a impressão de ser eritrócitos parasitados ao lado de formas circulares, ovais, alongadas e fusiformes que assumem vários aspectos, como de peixes, anfíbios (girino), répteis, aves e até de mamíferos.

Estará acontecendo uma perda da virulência ou uma mutação da cepa $\mathrm{Y}$ do Trypanosoma cruzi?

DESCRITORES: Trypanosoma cruzi. Hematopiese. Formas jovens $T$. cruzi.

\section{REFERENCES}

1. CHAGAS C - Nova tripanosomiase humana. Estudo sobre a morfologia e o ciclo evolutivo do Schizotrypanum cruzi, n. gen, n. sp. agente etiológico de nova entidade mórbida do homem. Mem Inst Oswaldo Cruz, 1909; 2: 62.

2. SILVA LHP \& NUSSENZWEIG V - Sôbre uma cepa de Trypanosoma cruzi altamente virulenta para o camundongo branco. Folia Clin \& Biol (S. Paulo), 1953; 20: 191-208.

3. OKUMURA M - Chagasic Megacolon. In: WORLD CONGRESS OF THE INTERNATIONAL COLLEGE OF SURGEONS, $19^{\text {th }}$. Proceedings, Lima-Perú, 1974; 3: 1931.

4. OKUMURA M - Pathogenesis of chagasic myocarditis. (An experimental study). Rev Hosp Clin Fac Med S Paulo 1996, 51: 166-174.

5. OKUMURA M, SILVA PLS, NUNES EV et al. - Young forms of Trypanosoma cruzi in the circulation of experimentally infected mice. Rev Hosp Clin Fac Med S Paulo 1998, 53: 275-276.
6. MORAIS-REGO S - Sobre o encontro de formas tissulares de Trypanosoma cruzi (Chagas, 1909) em esfregaço de sangue de camundongo branco (Mus musculus). Folia Clin \& Biol 1956; 26: $17-46$

7. ANDRADE $Z$ \& ANDRADE SG - Patologia. In BRENER Z \& ANDRADE Z - Trypanosoma cruzi e doença de Chagas. Rio de Janeiro. Guanabara Koogan, p. 199-248.

8. ROBERTTSON S, KENEDY M \& KELLER G - Hematopoietic Commitment During Embryogenesis. In: ORLIC D, BOCK TA \& KANZ L - Hematopoietic Stem Cells - Biology and Transplantation. Annals of New York Academy of Sciences 1999; 872: 9-16.

9. OGAWA M \& MATSUNAGA T - Humoral Regulation of Hematopoietic Stem Cells. In: ORLIC D, BOCK TA \& KANZ L Hematopoietic Stem Cells - Biology and Transplantation. Annals of New York Academy of Sciences, 1999; 872: 17-24. 
10. COOPER DD \& SPANGRUDE GJ - Evolutionary Consideration in Hematopoietic Development. In: ORLIC D, BOCK TA \& KANZ L - Hematopoietic Stem Cells - Biology and Transplantation. Annals of New York Academy of Sciences 1999; 872: 83-93.
11. EBERT D - Experimental evolution of parasites. Science 1998; 282: 1432-1435.

Received for publication on the 27/04/99 